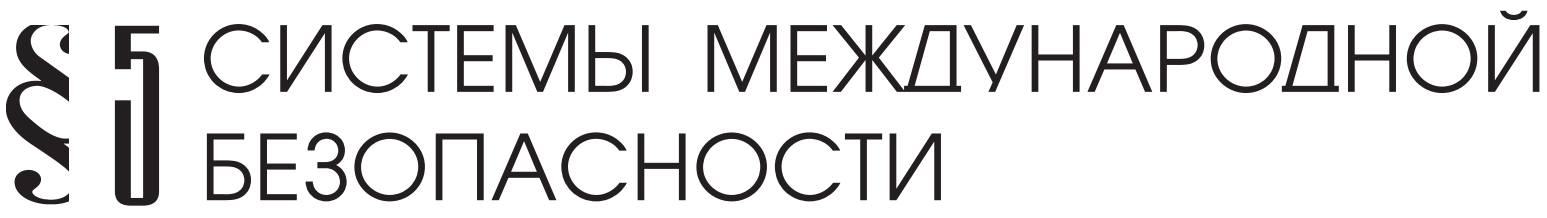

Манойло А.В

\section{«РУССКАЯ ВЕСНА» VS «АРАБСКОЙ ВЕСНЫ»: РОЛЬ РОССИИ В УРЕГУЛИРОВАНИИ СИРИЙСКОГО КОНФЛИКТА}

\begin{abstract}
Аннотация: Настоящая статья посвящена исследованию гражданской войны в Сирии, в которую страна погрузилась в результате осуществления Соединенными Штатами Америки проекта "иветных революций" u "управляемого хаоса" на Ближнем Востоке и в Северной Африке. В статье подробно анализируются цели, задачи, формы и методы борьбы участников сирийского конфликта, как выступающих на стороне правительства Сирии, так и относящихся к непримиримой ("Исламское государство», запрещуенное в Российской Федерачии) и «умеренной» оппозичии. Отдельно исследуется роль США, Туриии и монархий Персидского залива. Методологической основой исследования является системный, структурно-функииональный, сравнительно-политический подходы, методы анализа, синтеза, индукиии, дедукиии, наблюдения. Специальной линией прописывается роль внешней политики России на сирийском направлении в борьбе с международным терроризмом в контексте непростых отнотений с Соединенными Штатами, проводящими свою антитеррористическую операцию в регионе. Отмечается, что именно участие России в сирийском конфликте поставило точку в сценарии иветной революиии «Арабской весныl», сохранив сирийскую государственность и, как следствие, возможность народу Сирии самому выбирать свою судьбу.
\end{abstract}

Ключевые слова: Геополитика, Россия, мировая политика, внешняя политика США, государственный переворот, дипломатия, международные конфликты, государство, безопасность, «иветные революиии».

Abstract: This article is dedicated to the research of the civil war in Syria, which broke out as a result of the project of "color revolutions" and "controlled chaos" executed by the United States in the Middle East and North Africa. The article presents a detailed analysis of the goals, tasks, format, and methods of the fight in the Syrian conflict by the Syrian government, as well as those who belong to the irreconcilable "Islamic State" (condemned by the Russian Federation) and the "moderate" opposition. A special attention is given to the role of the United States, Turkey, and the royalty of the Persian Gulf. A separate place is dedicated to Russia's foreign policy with regards to Syria in the fight against international terrorism within the context of complicated relations with the United States who also conduct their own antiterrorist operation in the region. The author states that it is namely Russia's participation in the Syrian conflict effectively put the stop to the color revolution of Arab Spring, preserving Syrian statehood, and consequently enabling the Syrian people to choose their own future.

Keywords: International conflicts, diplomacy, coup d'état, U.S. foreign policy, world politics, Russia, geopolitics, state, security, color revolutions.

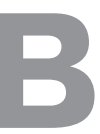

ойна в Сирии, ставшая кульминацией цветных революций «Арабской весны», сегодня является витриной стратегии управляемого хаоса, насаждаемого США по всему миру во имя «идеалов и ценностей демократии». Для того, чтобы понимать истинные причины разжигания гражданской войны в полностью благополучной стране, полностью себя обеспечивавшей, с нулевым внешним долгом, устойчивой валютой и растущей экономикой, в стране, где мирно уживались представители самых разных конфессий, необходимо проанализировать мотивы США, побудившие их разрушить всю систему ближневосточной безопасности, базировавшейся на устойчивых и, в целом, лояльных Западу светских режимах - в Тунисе, Египте, Сирии, Йемене, и отчасти даже в Ливии (после потепления отношений с США в 2008-2009 гг.). Ведь именно благодаря США на Ближнем востоке возник проект «ИГИЛ», который затем вышел из-под контроля американцев (также как в свое время это сделала Аль-Кайда). Сегодня уже очевидно, что, если бы не США с их «Арабской весной», не было ни ИГ, ни международного террористического интернационала, сформировавшегося вокруг этой организации, ни глобальной террористической 
угрозы для всего Западного мира (и незападного, кстати, тоже). Только благодаря цветным революциям «Арабской весны», демонтировавшей большинство светских режимов в арабских странах, исламисты и террористы смогли поднять голову и перейти в наступление, нацеленное на захват власти. Если бы не США и «Арабская весна», не было бы на землях Сирии и Ирака «всемирного исламского халифата», не возникли бы пока еще эфемерные образования «вилайет Хорасан», «вилайет Синай» и «вилайет аль-Андалуз», точно указывающие на дальнейшие направления экспансии исламистов. Если бы не вмешательство США. Ближний восток жил бы своей (пусть непростой, но своей) мирной жизнью.

Соединенные Штаты Америки - страна, которая учит мировое сообщество, как строить демократию и соблюдать права человека. И они значительно продвинулись в этом направлении: их атлантическая модель демократии считается эталонной для всей западной цивилизации. Многие страны мира, равняющиеся на запад, строят у себя политический режим, повторяющий или имитирующий североамериканскую модель демократического общества. Не меньшее количество стран и народов критикуют американскую демократию за агрессивность, склонность к неограниченной и бесконтрольной экспансии, за приверженность к двойным стандартам, и критикуют обоснованно. Однако сегодня не имеет смысла рассуждать о том, хороша или плоха демократия, построенная Соединенными Штатами и навязываемая ими всему миру. Можно говорить лишь о тех способах, методах и инструментах, которыми она насаждается.

Важно отметить, что США, создав собственную модель демократии, сделали еще одну модель - более упрощенную - на экспорт: именно эту модель США стали навязывать другим странам, принуждая их преобразовывать свой политический строй под англосаксонские либерально-демократические стандарты. Это привело к тому, что в незападных странах стали формироваться режимы, лишь внешне напоминающие демократические и имитирующие демократическую форму правления. Как следствие, они оказались неустойчивыми и очень зависимыми от патронажа со стороны США; ключом к их взлому и демонтажу стали цветные революции.

Посмотрим, как начинался и чем завершился экспорт демократии в тех странах, которые попали в зону особого внимания США.

Вторжение американских войск в Афганистан началось на фоне событий 11 сентября 2001 года, поставивших перед американским обществом новую глобальную задачу - борьбы с международным тер- роризмом. Объектом атаки была выбрана Аль-Кайда - террористическая организация, созданная при содействии ЦРУ для борьбы с советским военным присутствием в Афганистане. Ее лидер - Усама бен Ладен - на долгие десятилетия стал «лицом международного терроризма».

Целью последовавшей за терактами 11 сентября военной операции стало уничтожение международных террористов в «их логове» - на базах Аль-Кайды в Афганистане и недопущение новых нападений террористов на США со своих баз; ни о какой сверхзадаче построения демократического государства речи в принципе не шло. Большинство из этих целей были достигнуты уже к концу 2002 года. С вмешательством США в конфликт в Афганистане наступление талибов на Северный альянс было остановлено; в последовавшем за этим контрнаступлении основные военные силы талибов были частично рассеяны, частично уничтожены. К концу 2002 года уже ни о каком организованном военном сопротивлении со стороны талибов речи вообще вестись не могло; резкий переход от наступления к поспешному уходу практически со всех захваченных территорий привел высшее руководство движении Талибан в состояние глубокого замешательства, сменившегося состоянием прострации.

Вместе с тем, решив свои военные задачи, США из страны не ушли, а начали строить там новое демократическое государство, способное само себя защитить. Это привело к тому, что страна на долгие годы оказалась оккупированной США и их союзниками; демократия, выстроенная под руководством американских инструкторов, носила имитационный характер и держалась только на военном присутствии; США не спешили уничтожать талибов, а напротив начали с ними сотрудничать; погиб еще один миллион мирных жителей и т.д.

Вспомним, каким был Афганистан до и после вторжения США и их союзников по НАТО.

В 2003 году американцы вспомнили про Ирак, в котором все еще оставался у власти авторитарный режим Саддама Хусейна.

С этим режимом не удалось разобраться во время операции «Буря в пустыне» по одной простой причине: когда США и их союзники начали громить войска Саддама, в Ираке вспыхнуло мощное шиитское восстание, поддержанное Ираном. США действительно испугались: если бы к власти пришли шииты, Ирак мог бы стать иранским протекторатом.

Тогда США специально отвели свои войска для того, чтобы Саддам вывел из бункеров элитные дивизии национальной гвардии, не участвовавшие 
в битве с Западом. Саддам это сделал, и шиитское восстание было подавлено.

Теперь, спустя 10 лет, США решили поставить окончательную точку и уничтожить режим Саддама Хусейна, создав на его месте марионеточное демократическое правительство. Это им удалось: в ходе упорных боев иракская армия была уничтожена, Саддам найден и казнен, многие иракские командиры были подкуплены заранее (американские рейнджеры возили чемоданы долларов в тыл иракских войск, покупая генералов-изменников) и сопротивления не оказали. Формальным поводом для вторжения послужило наличие в стране ОМП, которое так и не было обнаружено.

Давайте вспомним, что представлял из себя Ирак до и после вторжения американских войск. Это было стабильное государство, одно из лидеров Арабского мира, региональный центр власти, страна, в которой бензин был дешевле воды.

В 2003 году Каддафи согласился «утилизировать» свое оружие массового уничтожения и осудить терроризм ради налаживания отношений с Западом. Позже он произвел репарации семьям пассажиров рейса №103 в результате теракта 1988 года. Западные СМИ нередко отмечали, что Ливия постепенно «оттаивает».

Тем не менее, Каддафи держал свою страну железной хваткой, это не устраивало США, и в феврале 2011 года Ливию охватила гражданская война. Центром мятежа стал город Бенгази. Против Каддафи выступили мятежники-исламисты, получившие оружие и финансирование по каналам ЦРУ. Под давлением США Совет Безопасности ООН принял резолюцию о создании над Ливией беспилотной зоны, что создало условия для проведения западными странами - Англией и Францией - масштабной наземной операции в поддержку так называемой «демократии» и «демократических сил».

Каддафи и верные ему войска мужественно сопротивлялись, и даже нанесли англо-французам несколько чувствительных поражений, поставивших эту военную авантюру на грань поражения. И только вмешательство США, пришедшего на помощь союзникам по НАТО, смогло переломить ситуацию.

Сам Каддафи, отступивший в родной для него город Сирт, сопротивлялся до последнего и, попав раненым в плен, был убит при загадочных обстоятельствах. Если бы он остался жив, он наверное многое бы сумел рассказать, о чем они договаривались с США в 2008 - 2010 годах, когда Ливию посетила Кондолиза Райс, и СМИ были наполнены сообщениями о новой эре взаимоотношений между Ливией и США.
Кстати, на уничтожении Каддафи вопреки воле Пентагона и разведки настаивала именно Хиллари Клинтон, подготовившая доклад, в котором данные об угрозе со стороны Каддафи были намеренно сфальсифицированы. Та самая Хиллари, которая сегодня претендует в настоящее время на пост президента США.

Вспомним, какой была Ливия до и после свержения режима Каддафи и прихода к власти новых проамериканских «демократических» сил.

Наиболее ожесточенные бои развернулись в родном городе Каддафи Сирте. Там был второй Сталинград: город был до основания разрушен, местное население уничтожено.

В Йемене в результате Арабской весны президент Салех был вынужден бежать из страны, передав власть премьер-министру - тому самому, на которого указали США.

С этого момента страна, пережившая благодаря США «арабскую весну», вступила в зону турбулентности. Шииты-хуситы, проживающие на севере Йемена и поддержавшие арабскую весну, результатами «весны» не удовлетворились и в 2014 году развязали масштабное наступление на суннитские территории, взяли столицу Йемена Сану и двинулись дальше, на земли, контролируемые йеменской ячейкой Аль-Кайды, которая еще в 2012 году признала верховенство ИГ. Суннитские государства региона и их основной союзник - США - не на шутку всполошились: за спиной хуситов стал все отчётливее проступать Иран, снабдивший их оружием.

США, обеспокоенные активностью саудовцев, решивших стать главными полицейскими в регионе и тем самым вытеснить оттуда американцев, направили весной 2015 года в Аденский залив крупное соединение кораблей: авианосец, ракетный крейсер и три десантных корабля с 2000 морских пехотинцев на борту. Это - весьма серьезные силы, истинная цель которых - не перехват иранских конвоев, а сдерживание военно-политической мощи Саудовской Аравии и той военной коалиции, которую ей удалось собрать для войны с хуситами. Так идет установление демократии в этой многострадальной стране.

Ливийский сценарий американцы применили и в Сирии. В 2011 году США окончательно перестал устраивать политический режим Б. Асада, опирающийся на алавитов - шиитское меньшинство, удерживающее в Сирии власть. США готовили военную операцию против Ирана, а Сирия является основным (и единственным) союзником Ирана на Ближнем Востоке. Вашингтон опасался, что в случае начала агрессии против Ирана Б. Асад ударит в тыл американских войск. Поэтому его надо было устранить. 
Под руководством США в Сирии началась цветная революция, быстро переросшая в вооруженный мятеж. Основной движущей силой мятежа стали сунниты-джихадисты, выступающие против лояльных Асаду шиитов-алавитов. Асад, имевший мирную профессию врача-офтальмолога, был вынужден взяться за оружие и руководить обороной страны.

Интересно, что мятеж против авторитарного правления Б. Асада начался как раз в тот самый момент, когда он решился на демократические реформы: законодательство страны было либерализовано, военное положение, сохранявшееся в стране в течение 40 лет - отменено.

Гражданская война привела к гибели огромного числа мирного населения, к геноциду шиитов и христиан, к установлению на почти трети территории Сирии диктатуры ИГ.

Вспомним, какой была Сирия до и после вмешательства в ее внутренние дела Соединенных Штатов. Это было процветающее государство, полностью обеспечивающее себя продуктами и товарами, страна без внешнего долга.

Сегодня Сирия продолжает сопротивляться, удерживая фронт двумя дивизиями и двумя бригадами, состоящими из алавитов. Основная часть сирийской армии, состоящая из суннитов, заняла выжидательную позицию и участия в войне не принимает. Б. Асаду рассчитывать на нее не стоит, в отличие от алавитов, которым в случае поражения режима Асада грозит геноцид. Основным противником Асада выступает Свободная сирийская армия и ИГ - террористическая суннитская группировка, ставящая своей целью создание всемирного исламского халифата.

Несколько раз Сирия была на грани прямого вооруженного вмешательства США и стран Запада, но каждый раз ее что-то спасало: в первый раз это было вето, наложенное Россией и Китаем на проект резолюции, разрешающей интервенцию; второй раз это была инициатива России по утилизации сирийских запасов химического оружия, подкрепленная посылкой российского флота к сирийским берегам, которая застала американцев врасплох и на время смешала их планы.

Так получилось и на этот раз: по просьбе руководства Сирии и по согласованию с ним Россия 30 сентября 2015 г. начала воздушную операцию ограниченного контингента своих Воздушно-космических сил (ВКС) против международной террористической организации «Исламское государство» (ИГ) и других экстремистских организаций, захвативших в течение последних трех лет большую часть территории Сирии, а также значительную часть Ирака.
Сегодня, давая оценку совместным военным успехам России и Сирии в борьбе с международным терроризмом, многие эксперты продолжают задаваться вопросом: зачем Россия, находясь в сложном международном положении и переживая острый экономический кризис, ввязалась в военный конфликт между режимом Асада и «сирийской умеренной оппозицией», из состава которой Соединенные Штаты только недавно исключили «Исламское государство» (ИГ). По данным Генерального штаба ВС России, всего за один месяц российские самолеты в Сирии совершили 1391 боевой вылет, уничтожив при этом 1623 объекта боевиков [1]. Кроме того, 7 октября 2015 г. по выявленным стационарным объектам военной инфраструктуры террористов на сирийской территории был нанесен удар 26 крылатыми ракетами «Калибр» с кораблей и катеров Каспийской флотилии ВМФ России. Начало военной операции, успешное для российско-сирийской коалиции, население России восприняло с несомненным энтузиазмом: Сирия - не Украина, она далеко, и для большинства российских граждан эта война воспринимается как увлекательная компьютерная игра. Действительно, российская авиация «бесконтактно» поражает цели на территориях, контролируемых ИГ, «Джабхат ан-Нусра» и другими исламистскими группировками; под ударами ВКС РФ террористы бегут, оставляя свои долговременные укрепленные позиции; «прокачанные» ракеты класса земля-поверхность «Калибр», запущенные с кораблей Каспийской военной флотилии, поражают цели на территории Сирии, предварительно пролетев над Ираном, Ираком и позициями сирийской армии. Все это, несомненно, выглядит эффектно и подчеркивает значительно возросшую эффективность российских вооруженных сил и вызывает обоснованные опасения у наших военно-политических соперников. Особенно их поразил «краш-тест» российских крылатых ракет, долетевших от Каспия до Сирии: сначала в западных СМИ никто просто отказывались верить в то, что российские ракеты способны летать на такие расстояния, и все ждали сообщения от Ирана о том, что все, запущенное с Каспия, попадало на его территории; затем эта позиция сменилась откровенно паническими настроениями, которые волшебным образом увеличили и боевые возможности, и дальность новейших российских крылаток: теперь, по мнению западных СМИ, они в состоянии долететь до Нью-Йорка и Вашингтона «без дозаправки в воздухе».

Между тем, эйфория по поводу успехов российских вооруженных сил-явление временное, она рано 
или поздно пройдет, и на первый план выйдет суровая объективная реальность: война в Сирии - надолго, это конфликт с непредсказуемым развитием, и Россия, оказавшись в самом его центре, став прямым участником боевых действий, в самое ближайшее время встанет перед необходимостью разработки долговременной военной стратегии на сирийском ТВД. Считать, что в Сирии можно ограничиться только авиационными ударами по позициям исламистов, и сама операция ВКС РФ является всего лишь «героическим рейдом красной конницы по тылам махновцев», - по меньшей мере, наивно. Вот почему необходимо тщательно разобраться в том, зачем России сирийская война, если есть Украина; какие мотивы стали основными побудительными причинами прямого участия России в вооруженном конфликте между Б. Асадом и противостоящим ему мятежниками; было ли это неизбежностью, или просто маркетинговым ходом, призванным поставить Запад в неудобную позу и одновременно отвлечь внимание от затяжного конфликта в Украине; стоит ли сирийская военная кампания тех затрат, которые ложатся на дефицитный российских бюджет, в о время как в стране не хватает денег для того, чтобы содержать учителей и врачей, индексировать пенсии; и наконец, сможет ли Россия также легко выйти из конфликта, как она в него вошла, и какова будет цена «обратного билета» - ведь известно, что в конфликт проще войти, чем из него выйти. Все эти вопросы остаются актуальными, и, по мере того, как Россия все больше будет втягиваться в ближневосточные дела, их острота будет нарастать.

Прежде всего, определимся с пониманием того, кто и с кем сегодня воюет в Сирии. Война в Сирии всего лишь часть процессов, которые охватили весь Ближний Восток и Северную Африку после «цунами» так называемых революций «Арабской весны», уничтоживших светские режимы в целом ряде стран, являвшихся лидерами Арабского мира - в Египте, Ливии, и практически уничтоживших светский режим в Сирии. Одновременно с этим под напором «Арабской весны» была уничтожена система коллективной безопасности, позволявшая светским режимам Сирии, Ливии, Туниса, Египта и др. стран десятилетиями сдерживать натиск исламистов, жестоко подавлять любые попытки террористов вмешаться в мирную жизнь. Сегодня уже очевидно, что революции «Арабской весны» истинными революциями как раз и не были, это англосаксонские технологии организации государственных переворотов, известные во всем мире под названием революций «цветных». США, решившие в конце 2010 года переформатировать весь Арабский восток, погрузив его с помощью цветных революций в «управляемый хаос», преследовали свои цели: они надеялись тем самым обеспечить себе надежный стратегический тыл в преддверии готовившейся ими наземной военной операции против Ирана. Именно поэтому удар цветных революций пришелся сначала на Ливию, с которой США так и не удалось договориться по принципиальным вопросам, даже не смотря на беспрецедентное сближение двух стран в 2008-09 гг., в ходе которого США уже практически согласились признать режим Каддафи легитимным; а затем - на алавитскую Сирию, которая была на тот момент единственным военно-политическим союзником Ирана на Ближнем Востоке, представленном, в основном, суннитскими политическими режимами. Этот удар был настолько силен, что в мае 2012 года никто не давал режиму Асада больше двух недель существования. Несомненно, так бы оно и было, если бы не одно «но»: уже в сентябре стратегические планы США в регионе поменялись (наземную операцию против Ирана пришлось отложить) и Вашингтон временно потерял к Сирии интерес. Это и позволило Асаду выжить, а всему остальному миру говорить о том, что в Сирии по неизвестным причинам цветная революция «забуксовала»- впервые за всю историю «Арабской весны». Правда, следует отметить, что по целому ряду объективных причин «Арабская весна» не получила своего развития в Марокко и Алжире (они на тот момент не были в фокусе внимания США и стихийные волнения там так и остались стихийными); в Бахрейне революция «Арабской весны» была подавлена танками Саудовской Аравии и Катара.

Как известно, цветные революции не решили проблему с «демократизацией» Арабского востока - они лишь разрушили политическую жизнь арабских стран и полностью демонтировали светские политические режимы, систему политических институтов, образовав «вакуум» власти. В образовавшийся «вакуум» хлынули те самые силы, которые светские режимы Туниса, Ливии, Египта, Сирии и других стран жестоко и бескомпромиссно подавляли на протяжении 30-40 лет: этими силами стали исламисты и террористы. В Египет в результате «Арабской весны» пришли «Братья-мусульмане»; в Сирии против Башара Асада выступили джихадисты со всего мира, основной ударной силой т.н. «Сирийской свободной армии» стали отряды сирийской ячейки Аль-Кайды, а впоследствии к этим силам присоединилось ИГИЛ. Американцы, к этому моменту потерявшие интерес к Тунису, Египту, Ливии (там вообще после свержения Каддафи все было пущено на самотек, кроме распределения нефтяных контрактов), стали активно сотрудничать с антиасадовскими силами, видя в них инструмент 
«окончательного решения сирийского вопроса». При этом США проявили характерную для них гибкость, выстраивая партнерские отношения с теми самыми силами, против которых они много лет воевали в Афганистане, Ираке и по всему миру: с Аль-Кайдой и Талибаном, боевики которых сформировали ядро исламистских группировок, объединенных западными политтехнологами под единым брендом «Сирийской свободной армии», а в последствии - под брендом «умеренной сирийской оппозиции». В этом нет ничего удивительного: в Афганистане между США и талибами также выстроились отношения «стратегического партнерства», создававшие в течение многих лет иллюзию непримиримой борьбы США с международным терроризмом и, одновременно, оправдывавшей присутствие американских и натовских войск ан земле суверенного Афганистана. В Сирии и Ираке американцы всего лишь повторили привычный для них формат сотрудничества с исламистами - на фоне общей имитации борьбы с ними. Учитывая, что и Аль-Кайда, и ИГ изначально создавались при прямом участии Соединенных Штатов и были их политтехнологическим «проектом», нет ничего удивительного в том, что определенное чувство «родства» между исламистами и США сохранилось, что не может не способствовать их сближению при решении общих целей и задач.

Прямым результатом арабских революций стала стремительная исламизация Арабского востока: именно благодаря «Арабской весне» Ливия и Сирия погрузились в пучину гражданской войны; в Йемене развернулась гражданская война между хуситами (шиитами-зейдитами) и суннитским правительством, пришедшем к власти при поддержке США в 2011 году, которое поддерживают войска Саудовской Аравии, Катара и созданной ими «волевой коалиции» из 13 государств, ведущих против населения Йемена открытую военную интервенцию; именно благодаря «Арабской весне» окрепло и набрало силу ИГ, цель которого - создание всемирного халифата, ведет войну сразу на четырех фронтах: иракском, сирийском, египетском (на Синае) и Ливийском (в районе Сирта), а в ближайшее время намерено перенести боевые действия в Афганистан (для того, чтобы окончательно подчинить себе талибов), на Кавказ и даже в Европу, уже поделенную исламистами на два «вилайета». Сегодня уже очевиден тот факт, что, если бы не «Арабская весна», ИГ никогда бы не возникло, а многочисленные ячейки Аль-Кайды по всей территории, от Ливии и Египта до Ирака, так и остались бы маргиналами, сидели бы тихо по своим «медвежьим углам» и боялись «высунуть нос».
В Сирии режиму Башара Асада противостоит международный террористический интернационал, состоящий из ИГ, различных региональных группировок сетевой террористической организации АльКайда и прочего сброда, состоящего из террористов, исламистов, наемников и просто бандитов, гордо именуемых Соединенными Штатами «умеренной сирийской оппозицией». Наиболее опасной из них, в контексте текущей политической ситуации в регионе, является ИГ, но при этом сразу следует оговориться: помимо ИГ, против Асада действует около сотни исламистских группировок, большинство из них ничем от ИГ не отличаются (найдите десять отличий между ИГ и Джабхат ан-Нусрой), поэтому их часто путают; три-четыре группировки, входящие в т.н. «умеренную оппозицию» и конфликтующие с ИГ (такие как Джабхат ан-Нусра, боевое крыло сирийской ячейки Аль-Кайды), по боевой мощи приближаются к ИГ или даже превосходят его по числу боевиков (так, у фронта Ан-Нусры не меньше 45 тысяч боевиков - это сравнимо с ИГ или даже превосходит ИГ по численности).

Как указывает А.И. Гушер, «за последние несколько лет ИГИЛ превратилась в сплоченную и хорошо вооруженную террористическую организацию. Это стало возможным благодаря комплектованию ее боевых формирований большим числом оказавшихся не у дел профессионально подготовленных бывших военнослужащих иракской армии Саддама Хусейна и наемников из других стран, захвату радикалами большого количества оружия, военной техники и боеприпасов бывшей иракской армии, а также установлению «Исламским государством» контроля над добычей нефти на ряде иракских и сирийских нефтяных месторождений. Нелегальный вывоз нефти и нефтепродуктов по демпинговым ценам в Турцию и в другие страны дает ИГИЛ значительные средства для закупки вооружений, оплаты услуг наемников и собственного актива. Здесь же следует указать на организацию поставок оружия и боеприпасов антиправительственным сирийским организациям спецслужбами Запада, а также арабскими монархиями региона, в первую очередь Катаром и Саудовской Аравией» [2].

ИГ самим фактом своего существования обязано внешней политике США, которые в 2006 году создали эту группировку на базе иракской ячейки Аль-Кайды для борьбы с режимом Башара Асада; кадровым ядром боевых подразделений ИГ стали солдаты и офицеры бывшей иракской армии, от которых отказалось новое правительство Ирака. Важно понимать, что на жесткой политике десуннизации и «дебаасизации» (от аббревиатуры «БААС» 
- политическая Партия всеарабского возрождения, к которой принадлежал С. Хусейн и к которой принадлежит Б. Асад) послевоенного Ирака настаивало не шиитское большинство - настаивали именно Соединенные Штаты, создавшие, тем самым, ресурсную базу для набирающего силу исламистского движения нового типа. В результате этой непродуманной политики Соединенных Штатов (а, может, напротив, очень продуманной и просчитанной) ИГ контролирует до 70\% территории Сирии, значительную часть Ирака; располагает боевой силой в виде 40-50 тысяч отборной пехоты, не испытывает проблем с оружием, которое оно получает в виде «спонсорской помощи» от стран, использующих ИГ в своих целях, или закупает за валюту, полученную от продажи Турции нефти по демпинговым ценам, или получает от самих американцев, которые очень часто путают группировки, относящиеся к ИГ и к поддерживаемой США «умеренной оппозиции»; обладает развитой системой военно-гражданской администрации, созданной ими на захваченных территориях. Все это позволяет ИГ вести наступательные действия одновременно сразу по четырем стратегическим направлениям, что подчеркивает военно-экономический потенциал этой группировки. Боле того, ИГ постепенно превращается в ядро сетевой организации - своеобразной террористической «федерации», в которую на правах полного иерархического подчинения входят различные исламистские группировки, действующие в Азии Африке, Европе - такие как узбексакая Хизб-утТахрир, нигерийская Аш-Шабаб, и даже некоторые ячейки Аль-Кайды, с которой ИГ разделяют непримиримые противоречия, особенно, в вопросах политического руководства: так, йеменская ячейка Аль-Кайды в 2014 году официально признала «верховенство» ИГ.

Наличие в рядах боевых формирований ИГ «значительной прослойки военных профессионалов и большого числа имеющих боевой опыт иностранных наемников и советников (по данным Минобороны РФ - около 30 тыс., в том числе до 7 тыс. человек из России и других стран СНГ) придает формированиям террористов на территории Сирии существенную боевую устойчивость при ведении ими боевых действий против регулярной сирийской армии» [2].

Вместе с тем, сами сирийцы утверждают, что ИГ - это, во многом, растиражированный бренд; его опасность никто не отрицает, но при этом подчеркивается, что среди «умеренной оппозиции» есть группировки, более опасные, многочисленные и жестокие, чем ИГ. Речь идет о Джабхат ан-Нусре, сирийской ячейке Аль-
Кайды. Именно эти группировки Запад стремится накрыть «зонтиком» «умеренной сирийской оппозиции», рассчитывая с помощью этих сил окончательно додавить режим Асада, а Россия наносит по их позициям воздушные удары. В этом плане американцы проявляют повышенную нервозность, поскольку речь идет о том, что Россия своими ударами уничтожает их собственный проект, их «активы», в формирование, подготовку и вооружения которых Соединенными Штатами вложены огромные деньги. Прямое требование США «прекратить уничтожать наши активы в Сирии» вызвано не столько опасениями потерять в лице сирийских исламистов удобные инструменты «грязного» решения собственных внешнеполитических проблем, сколько попыткой понять, кто же будет компенсировать ущерб от утраченных инвестиций, вложенных в радикальные формирования, успешно уничтожаемые в настоящее время российской авиацией, если Россия их полностью уничтожит. В последнем случае деньги американских налогоплательщиков в очередной раз «развеются по ветру».

«Исламское государство» ведет войну на четыpex фронтах: двух основных (сирийском и иракском) и двух вспомогательных (ливийском и синайском). На иракском фронте ему противостоят коалиционные силы иракских курдов (курдское ополчение пешмерга и вооруженные формирования курдских политических партий) и шиитское ополчение под руководством иранских офицеров. Федеральной армии Ирака в этой коалиции нет - она полностью уничтожена (частично - рассеяна) ИГ во время их первого наступления, когда боевики ИГ захватили Мосул (расположенный в 400-х км до Багадада) и затем практически вышли к предместьям Багдада (поставив под угрозу захвата Багдадский аэропорт). В настоящее время настиск ИГ сдерживают в основном шииттская милиция, в рядах которой много добровольцев из Ирана. Иракские курды оправились от удара и ведут довольно успешные боевые действия (перелом наступил в результате успешной обороны города Кабани), но сил их явно недостаточно для того, чтобы овладеть стратегической инициативой.

В Сирии боевые действия развиваются сразу в двух частях страны: сирийская армия, поддерживаемая с воздуха российскими ВКС, наступает сразу по трем направлениям - в провинции Латаккия, провинции Хома и в провинции Алеппо; с севера наступление на непризнанную столицу ИГ город Эр Ракку готовят США, собравшие для этого сирийских курдов (Демократический союз), христиан-ассирийцев (Высший военный совет) и присоединив к ним несколько мелких группировок из числа «умеренной 
сирийской оппозиции», давших свое согласие поддержать наступление. Россия успешно наносит удары по объектам ИГ и других исламистских группировок, значительная часть которых, несмотря на явную связь с Аль-Кайдой, входит в состав «умеренной оппозиции», поддерживаемой США. Сирийская армия после ударов российской авиации по позициям ИГ (в основном это огневые точки и бункеры, расположенные на господствующих высотах) планомерно зачищает пространство, заполненное разбежавшимися и рассредоточившимися на местности боевиками ИГ, продвигаясь медленно, часто встречая ожесточенное сопротивление и отбивая контратаки. Контролируя к моменту начала Россией воздушно-космической операции не более 14\% территории государства, сирийская армия в настоящий момент взяла под свой контроль уже около трети всей территории страны. Сирийских солдат в этом наступлении поддерживает корпус иранских и ливанских добровольцев, начитывающий примерно 50-60 тыс. бойцов.

Ливанские добровольцы - в основном, представлены бойцами ливанской Хезболлы. Их в Сирии около 12 тысяч.

Иранские добровольцы - это солдаты и офицеры Корпуса стражей исламской революции (КСИР), его одного из самых элитных подразделений - бригады специального назначения «аль-Кудс», предназначенной для ведения диверсионной войны на территории зарубежных стран, в различных регионах мира (аналог американских «зеленых беретов»). Возглавляет их генерал Касем Сулеймани - ветеран ирано-иракской войны, командир бригады «альКудс». Именно его спецназовцы сейчас приступили к штурму Алеппо - огромного по территории и хорошо укрепленного мегаполиса, часть которого контролируют правительственные войска, треть находится под контролем ИГ и еще одна треть - под контролем Аль-Кайды. При этом персы несут большие потери: так, недавно в районе Алеппо погиб уже третий по счету генерал КСИР. Военные эксперты прогнозирует большие потери среди иранских военных в «битве за Алеппо», поскольку, при всей внешне суровой репутации КСИР, ему явно недостает современного боевого опыта, а также опыта боевых действий в городах и городских агломерациях.

Сирийская армия, отвечающая за наземную фазу операции против ИГ, - это самая крупная (и, фактически, единственная) организованная сила, выступающая против ИГ и террористического интернационала. Состоит она в основном из алавитских частей, которые сохраняют верность Асаду и будут бороться с ИГ до конца. Помимо алавитов, на стороне Асада выступают исмаилиты, часть друзов, христиане, небольшая часть суннитов и часть шиитов-джафаритов, что составляет 40-50\% населения страны. Одной из причин стойкости алавитских частей (двух отдельных бригад, двух дивизий, ряда отдельных частей и формирований, подразделений государственной безопасности, контрразведки ВВС) заключается в понимании того, что для них эта война ведется за выживание: ИГ, входя в населённые пункты, вырезает всех, не принадлежащих к суннитской ветви ислама. Алавиты же - шиитская секта, которая представляет собой любопытную смесь ислама и христианства. Вместе с тем, сирийская армия слишком малочисленна для того, чтобы добиться в одиночку решающего перевеса над вооруженными формированиями исламистов. Вот почему Россия, начав с согласия сирийской власти воздушно-космическую операцию против ИГ и других террористических группировок, возродила надежду у народов, населяющих Сирию, в том, что на эту землю наконец-то придет мир, утраченный с началом «Арабской весны».

Гражданская война в Сирии, берущая свое начало в событиях «Арабской весны», с 2011 года развивалась нелинейно, с различной интенсивностью: так, в период интенсивного развития украинского кризиса 20132015 гг. вооруженный конфликт в Сирии был фактически заморожен, поскольку ни мятежникам, ни правительственным войскам в сущности не хватало сил для достижения решающего перевеса в вооруженном противостоянии. Попытки США пустить сирийский конфликт по ливийскому сценарию, проведя через СБ ООН резолюцию, разрешающую военную интервенцию, к результату не привели: Россия и Китай заблокировали прохождение подобной резолюции. Затем США несколько раз предпринимали попытки найти новые поводы - уже подзаконные - для вторжения в Сирию и повторения в ней иракского сценария: в Сирии было обнаружено химическое оружие, от которого США спасла все та же Россия, организовавшая программу его утилизации; затем были зафиксированы обстрелы турецкой территории, ответственность за которые была возложена на сирийскую армию. Но это тоже не привело к открытому вторжению экспедиционных войск западных стран в Сирию: вспыхнула Украина, и противостояние США и РФ переместилось на новую площадку, о Сирии временно забыли, и война там носила позиционный характер до тех пор, пока не набрало силу ИГ. Сегодня ИГ - крупнейшая угроза международной безопасности, в том числе в геополитическом плане, поскольку ИГ формирует на захваченных территориях исламский халифат протогосударственное образование нового типа, а 
противостоит этой угрозе Российская Федерация, развернувшая в октябре 2015 года воздушную операцию в Сирии (с разрешения сирийского правительства), сирийский режим Башара Асада, иранские и ливанские добровольцы, шиитское ополчение в Ираке, пешмерга и другие курдские группировки в иракском Курдистане, сирийские курды, поддерживающие в целом режим Асада, египетская армия на Синае и вооруженные отряды бывших оппозиционеров (режиму Каддафи) в Сирте (Ливия). При этом действия России в Сирии, воюющей против международных террористов, натыкаются на острую критику и даже угрозы со стороны США, Турции, КСА и других военно-политических союзников Вашингтона, которые настолько недовольны усилением геополитической роли России в регионе, что готовы встать на защиту исламистов и террористов (по крайней мере, из лагеря так называемой «умеренной оппозиции»).

Критикуя действия РФ в Сирии, США и их союзники пытаются не допустить создания в регионе коалиции под руководством Москвы. Делается это потому, что такая коалиция способна создать новую архитектуру связей во всем арабском мире [3].

В октябре 2015 года Саудовская Аравия и Турция присоединились к адресованным России призывам США прекратить авиаудары по позициям «умеренной оппозиции» в Сирии. Между тем, ни США, ни их союзники в регионе пока не смогли объяснить, где именно находится эта «умеренная оппозиция» и как ее отличить от террористических структур. Финансируемые США и их союзниками антиправительственные формирования в Сирии давно смешались с чисто террористическими структурами - такими как запрещенные в России организация «Исламское государство» и «Джабхат ан-Нусра». Это всем хорошо известно, и разговоры об «умеренной оппозиции» - лишь политический ход. Главная цель этого хода - спасти от разгрома хотя бы часть террористических по сути структур, в которые в прошлом были вложены немалые средства. США и их союзники - Турция и многие из арабских монархий Персидского залива - долгое время формировали и выкармливали эту так называемую «оппозицию». Тратили деньги на приобретение оружия, на обучение новейшим методам ведения войны. То есть, это очень серьезный и дорогостоящий проект. И тут неожиданно Россия делает «ход конем» и начинает наносить удары по этому бизнес-проекту. К нынешнему моменту в этом проекте уже невозможно отличить «умеренных» оппозиционеров от «неумеренных». Например, к «умеренным» США относят «Джабхат ан-Нусра», а между тем это - организация, которая считает себя боевым крылом сирийской ячейки «Аль-Каиды». Головы они режут точно так же, как «Исламское государство», а может быть, даже еще более интенсивно: многие выложенные в сети ролики, которые относят к деятельности ИГ, на самом деле фиксируют казни, осуществленные боевиками «Джабхат ан-Нусра». Они нисколько не менее опасны, они отнюдь не «умеренные», просто они менее известны, чем разрекламированное «Исламское государство».

Обвиняя Россию в атаках на «умеренные» группировки, США и их союзники начали долгосрочную комбинацию, цель которой - сохранить американский контроль над регионом. Пока американцы имитировали борьбу с ИГ, Россия предприняла попытку организовать реально действующую международную антитеррористическую коалицию. И многие арабские страны пошли на сближение с Россией в этом вопросе. После этого США и их союзники испугались, что Россия сформирует под своим контрольным управлением некий интернациональный фронт, который сначала разберется с марионеточными исламистскими группировками, которые вооружали и обучали американцы и страны Персидского залива, а затем этот фронт будет выстраивать новую архитектуру международных отношений во всем арабском мире. Это не нравится монархиям Персидского залива - Саудовской Аравии и Катару, которые видят в этом угрозу их лидерству. Вместе с тем, даже им не стоит обольщаться относительно истинных намерений таких группировок как ИГ, которая пообещала взять штурмом Мекку и Медину и разрушить каабу. Выступая в защиту вроде бы полезных им сегодня террористических структур, эти страны совершают ошибку. Ведь, в отличие от США, они находятся в зоне прямой досягаемости боевиков ИГ и Аль-Кайды.

Вместе с тем, несмотря на военные успехи российских ВКС в первой фазе антитеррористической операции в Сирии и доводы разума, говорящие о необходимости и неизбежности борьбы с ИГ, следует отметить, что против прямого участия России в военном конфликте в Сирии существует не меньше доводов, чем за ее участие.

С одной стороны, важно понимать, что от терроризма никуда не спрячешься и никуда не убежишь: сломив сопротивление Асада, окрепнув и многократно увеличив свою мощь, террористы ИГ обязательно пойдут в Европу, в Центральную Азию, на Кавказ. Только тогда с ними справиться будет намного сложнее, чем сейчас, в Сирии и Ираке: ИГ, хотя и располагает значительными боевыми возможностями, пока еще глобальной военной угрозы не представляет. 
Боевиков ИГ пока еще недостаточно для того, чтобы установить всемирный халифат, но их число быстро растет за счет профессиональной пропаганды, делающей миссию ИГ привлекательной в глазах молодежи, массово вступающей в это движение. Поэтому, если сейчас с ИГ не покончить, больше такого шанса уже не будет. А это означает, что, «если понимаешь, что драка неизбежна, - бей первым». Кроме того, при прочих равных условиях с террористами и исламистами лучше воевать на чужой территории.

Как отмечает член Научного совета при СБ РФ, генерал-майор А.И. Гушер, «решение российского руководства по Сирии было просчитанным и стратегически обоснованным, а для многих зарубежных «партнеров» России еще и неожиданным»; Как и в случае с Крымом в 2014 году, решительные действия России на сирийском направлении снова оказались неприятным сюрпризом для политиков США, их союзников и западного разведывательного сообщества. Они владели информацией об активизации России на сирийском направлении, но не смогли собрать все имевшиеся в их распоряжении фрагменты развития ситуации в Сирии и вокруг нее в единую картину и сделать правильные выводы. По-видимому, они были под большим влиянием собственных представлений о неспособности и неготовности России пойти на столь решительные шаги за пределами собственной территории» [2].

Россия не цепляется за личность Асада: его политическую судьбу, также как и послевоенное устройство Сирии, может определить только сирийский народ. Но Россия никому, даже Соединенным Штатам, не позволит повторить в Сирии или любой другой стране ливийский сценарий. Не потому, что Россия сегодня сильна и в военном отношении, и в дипломатическом, а, в первую очередь, потому, что если ты закроешь глаза на то, что делают с твоим соседом, то завтра это могут сделать с тобой.

С другой стороны, не менее важно понимать, что сирийская война - это надолго: Сирия сегодня напоминает Афганистан или Сомали, это один кипящий котел гражданской войны, где все воюют против всех. Ввязаться в такой конфликт гораздо проще, чем выйти из него: так, к примеру, для того, чтобы американцам уйти из Ирака, Вашингтону потребовалось десять лет. Удастся ли России из этого конфликта выйти вовремя и без потерь - большой вопрос.

Во-вторых, очевидно, что воздушная операция России не уничтожит ИГ, хотя и заметно ослабит; сирийская армия уже сейчас сталкивается с ожесточенным сопротивлением, которое боевики ИГ оказывают на пересеченной местности, которая в принципе исключает возможность быстрого продвижения правительственных войск. Сирийцы - в принципе, неплохие вояки, но их все время надо поддерживать. Сил сирийской армии не хватит, чтобы взять Алеппо - возможно, иранцы им помогут, но даже в этом случае штурм Алеппо растянется на несколько месяцев и будет стоить больших потерь. Авиацией по нему работать нельзя - в городе, насчитывающем до начала войны более 3 млн. населения, все еще остается порядка 300-400 тыс. человек.

В-третьих, война - штука дорогая. По мере того, как Россия будет втягиваться в конфликт, расходы на войну будут расти - возможно, даже в геометрической прогрессии. Выдержит ли это российский бюджет, уже испытавший последствия кризиса и резкого падения цен на нефть - еще один большой вопрос.

В-четвертых, в США все чаще говорят о том, что Россию надо втянуть в Сирии в войну на истощение, сделать ей второй Афганистан. В этом плане США уже начинают поставлять оружие (в том числе ПЗРК) «умеренной оппозиции», которая передает его прямиком в руки боевиков ИГ. Понимая, что наступление сирийской армии рано или поздно выдохнется, и для наземной операции потребуются свежие силы, пехота и бронетехника, США очень надеются на втягивание России в наземную часть операции. В Вашингтоне в связи с сирийскими событиями в политической риторике демократов появился даже новый термин - «трясина», в которой Россия, по мнению США, должна увязнуть. Это - довольно реальная угроза, поскольку события могут пойти таким образом, что наземная операция для России станет вынужденной необходимостью.

Кроме того, в активе у США еще остается Украина, вокруг которой сегодня установилось временное затишье, но которую США не сбросили со счетов: заявляя о приверженности Минским соглашениям, США и НАТО ускоренно вооружают и обучают формам и методам ведения современной войны шесть армейских батальонов (5 батальонов ВСУ и 1 батальон нацгвардии). Против кого они предназначаются - известно. Согласно стратегическому плану США, втянувшись в войну в Сирии, Россия фактически окажется в ловушке: если в этом момент вновь вспыхнет гражданская война в Украине, России будет очень сложно противостоять экспансии США сразу на двух стратегических направлениях. И эта угроза тоже вполне реальна.

Вместе с тем, вмешательство России в конфликт в Сирии в современных условиях - это тот самый асимметричный ответ экспансии Запада, который пытается подчинить себе волю российского народа 
санкциями, угрозами, развязыванием вооруженных конфликтов у границ страны, попытками применения технологий цветных революций, информационной войной.

Для России военная операция в Сирии важна тем, что благодаря этому незаурядном внешнеполитическому ходу, ставшему неожиданным для США и во-многом спутавшему их планы в регионе, Россия фактически перехватила у Запада стратегическую инициативу на Большом Ближнем Востоке. В попытке ее вернуть США спешно готовят наступление курдов, ассирийцев и собственного спецназа на Ракку (нефтяную столицу Сирии и главный административный центр ИГ), надеясь показать, кто в борьбе с ИГ главный, и одновременно дать шанс исламистам «сдаться» и, тем самым, «сохранить себя для борьбы с абсолютным злом - режимом Асада» (как американцы делали в 1945 году, разоружая немецкие дивизии и сохраняя их кадры в специальных лагерях для будущей войны с СССР). Но эта спешка со стороны США уже никого обмануть не может: лидеры арабских государств все как один потянулись в Москву, интуитивно понимая то, что журналисты журнала Шпигель недавно (в октябре 2015 г.) сформулировали в явном виде: «Эпоха доминирования Запада осталась позади, Америка больше не устанавливает порядок в мире и не гарантирует его» [4]. В Европе это тоже прекрасно видят: именно поэтому 25 октября 2015 г. в Вене, на встрече глав внешнеполитических ведомств России, США, Саудовской Аравии и Турции, было принято политическое решение «сохранить режим Асада» до бесспорной военной победы над ИГ.

Основным инструментом реализации внешней политики США на Ближнем востоке (и не только) являются технологии цветных революций и управляемого хаоса. Разница между ними - только в объектах, на которые направлено воздействие: цветные революции - это технологии организации государственных переворотов и демонтажа политических режимов, их разрушительное воздействие направлено на политической режим, политическую систему и властные институты; объектом же технологий управляемого хаоса являются общественные объединения, родовые, племенные связи и структуры, а в государствах западного типа - институты гражданского общества. Технологии управляемого хаоса разрушают общественный уклад, демонтируют систему общественных отношений, «атомизируя» общество и делая его беззащитным перед технологиями цветных революций. В определенном смысле технологии управляемого хаоса готовят почву для успешного применения технологий цветных революций и в этом смысле всегда сопутствуют цветным революциям, выполняя подготовительные «сервисные» функции.

В мировой истории проблемы, связанные с демонтажем политических режимов, возникали всегда. Но прежде инструментами этого демонтажа выступали в основном силовые методы в их классическом понимании, применявшиеся в ходе вооруженных переворотов, локальных вооруженных конфликтов, гражданских войн и военных интервенций. И мировое сообщество сумело выработать действенные методы противодействия этой угрозе и создать эффективные механизмы политического регулирования этих процессов, в том числе на международном уровне: кто бы и как бы ни критиковал ООН, эта организация действует, и ее потенциал и возможности по управлению политической стабильностью и урегулированию международных конфликтов даже в условиях распада Вестфальской системы далеко не исчерпаны. Острота проблемы, связанная с угрозой вооруженных переворотов в различных странах мира, не перестает быть актуальной и не снимается с повестки дня, но в целом для мирового сообщества эта категория угроз является знакомой, и мировое сообщество знает, как на нее реагировать.

Вместе с тем, сегодня мир меняется, и на смену технологиям вооруженных переворотов приходят более тонкие технологии цветных революций, которые умело маскируются под истинные революционные движения и практически не встречают сопротивления со стороны как стран с вполне уже сложившейся демократией, так и государств восточного типа, сохранивших традиционный жизненный уклад. Повторение сценария цветных революций в Украине вызывает обоснованную тревогу, поскольку возникает и крепнет уверенность в том, что Украина - далеко не конечный пункт этого сценария, а разменная карта в той геополитической игре, в которой главный удар американских режиссеров цветных революций может быть направлен на Россию, Китай и Казахстан.

Причины возросшего внимания к цветным революциям кроются в том, что в течение последних трех лет в целом ряде государств, с вполне устойчивыми политическими режимами, произошли государственные перевороты, приведшие к полному или частичному демонтажу политических режимов, долгие годы успешно сопротивлявшихся с внешними и внутренними врагами: так, египетский, тунисский, сирийский и ливийский режимы успешно противостояли исламизму.

При этом в сценариях смены политических режимов в этих странах наблюдается поразительное сходство, в котором можно усмотреть многократное 
повторение одного и того же шаблона или организационной схемы, в которой угадываются общие черты так называемых бархатных революций, уничтоживших коммунистические режимы в странах восточной Европы после распада СССР.

Такое совпадение вряд ли можно назвать случайным, поскольку вероятность точного совпадения сценариев смены политических режимов в странах, заметно различающихся и по уровню политической организации власти, и по уровню социально-экономического развития, и по спектру нерешенных проблем, сравнительно (если не сказать ничтожно) мала.

В этом плане Сирия и Ливия кардинально отличаются от Украины и Грузии, однако, несложно отметить, что революция 2014 года в Украине (получившая название евромайдана) в точности совпадает со сценарием революции Арабской Весны в Египте, вплоть до стиля поведения противоборствующих сторон.

Все это может свидетельствовать о том, что на примере различных стран и регионов мы имеем дело с одним и тем же явлением - результатом применения технологий цветных революций. Однако, несмотря на яркое брендовое название, ничего революционного в них нет.

Даже западные СМИ сегодня отмечают, что цветные революции, которые они называют технологиями проведения операций по экспорту демократии через акции гражданского неповиновения, настолько отточены, что их методы превратились в руководство по смене политических режимов [5].

В связи с этим стоит более подробно остановиться на самом определении цветной революции и связанном с ним терминологическим рядом.

Цветные революции - это технологии осуществления государственных переворотов и внешнего управления политической ситуацией в стране в условиях искусственно созданной политической нестабильности, в которых давление на власть осуществляется в форме политического шантажа с использованием в качестве инструмента шантажа молодежного протестного движения.

Несмотря на существенные различия государств, в которых они вспыхивают, между собой (в геополитическом, социальном, экономическом плане и международном положении), все они укладываются в одну и ту же организационную схему, предполагающую организацию по шаблону молодежного протестного движения, преобразования его в политическую толпу и использование этой силы против действующей власти в качестве инструмента политического шантажа. Это прямо указывает на то, что цветные революции в принципе не могут быть реализацией объективных надежд и стремлений большинства населения.

Цель любой цветной революции - осуществление государственного переворота, то есть захват и удержание власти насильственным путем.

Объектом цветной революции выступают власть и властные отношения, предметом - политический режим.

У цветных революций есть необходимое и достаточное условия их успешной реализации.

Необходимое условие осуществления цветной революции - наличие политической нестабильности в стране, сопровождающейся кризисом действующей власти. Если политическая ситуация в стране стабильна, ее нужно искусственно дестабилизировать.

Достаточное условие - наличие специально организованного (по особой сетевой форме) молодежного протестного движения.

Отличительные черты цветных революций:

- В цветных революциях воздействие на власть осуществляется в особой форме - форме политического шантажа.

- Основным инструментом воздействия на власть выступает молодежное протестное движение.

Цветные революции только внешне напоминают настоящие революционные движения - в отличие от революций настоящих, вызванных объективным развитием исторического процесса, цветные революции - это технологии, успешно маскирующиеся под стихийные процессы. Они отличаются почти театральным уровнем драматургии, который западные политологи старательно пытаются выдать за самопроизвольное и стихийное проявление воли народа, внезапно решившего вернуть себе право управлять собственной страной.

В основе технологического сценария цветной революции лежит англосаксонская (североамериканская) идеология демократизации, предполагающая экспорт демократии, демократических институтов и ценностей в сопредельные страны. Технологии цветных революций на практике умеют применять только их авторы и разработчики - англосаксы. В любой стране, где начала разворачиваться цветная революция, следует искать северомериканский след.

В основе объяснения причин цветных революций лежат две версии: версия о стихийности и версия об инсценированности цветных революций (о случайности и неслучайности). Обе версии имеют право на существование и не являются бесспорными.

Сторонники стихийности цветных революций настаивают на том, что причиной революций являются объективные социальные противоречия, ко- 
торые находят свое проявление в формах народных бунтов и массового протеста «угнетенного» населения. В качестве таких причин называют нищету, усталость от режимов, тягу к демократическим переменам, демографическую ситуацию. Между тем, при детальном рассмотрении социально-политической ситуации в практически любой стране, в которой произошла цветная революция, нередко выясняется, что существующие в ней противоречия и социальные разрывы, хотя и стали катализатором последующих событий, но не были их основной и единственной причиной. Так, в Египте до цветной революции существовали так называемые дотации на лепешки, обеспечивающие доступность основного продукта - хлебных лепешек - для беднейших слоев населения, а в трущобах Каира на крыше каждой хижины можно увидеть тарелку спутникового телевидения; в Ливии граждане страны получали природную ренту (и массу других выплат), которая была настолько велика, что население совсем перестало работать и возложило обязанность трудиться на приезжих гастарбайтеров из того же Египта и др. африканских стран; уровень жизни в Тунисе - самом демократическом из всех авторитарных стран Африки - вплотную приближался к Южной Франции (Провансу и Лангедоку), а Южную Италию даже превосходил; одной из причин всплеска протестных движений в Сирии стало то, что Асад решил (без какоголибо давления) смягчить авторитарность режима и начал проводить либеральные преобразования, которыми тут же воспользовались исламисты и их покровители из США, и т.д.

Сторонники инсценированности цветных революций указывают на многократную повторяемость сценария (демократического шаблона) этих революций в различных странах мира, очень сильно различающихся как по особенностям государственного строя, так и по характеру социально-политических проблем. Они утверждают, что все цветные революции сделаны «под копирку», а вероятность повторения одного и того же события по одной и той же схеме в природе ничтожно мала. На основании этих выводов сторонники инсценированности цветных революций указывают на ряд признаков, по которым в любом внешне стихийном народном бунте можно установить цветную революцию.

В цветных революциях начисто отсутствует революционная идеология, что позволяет распознать в них подделку. Связано это с тем, что американцы - авторы цветных революций - не всегда понимают менталитет и психологию народа, которым они хо- тят принести «ценности истинной демократии», и не могут предложить им идеологию, которая будет органично принята всеми слоями общества.

Модель, лежащая в основе цветной революции, одна: это создание протестного движения, превращение его в политическую толпу и направление ее агрессии на действующую власть с целью заставить ее добровольно уйти с государственных постов и отказаться от управления страной. Такое давление на власть всегда происходит в форме шантажа, выдвижения ультиматумов под угрозой массовых погромов иреже - физических расправ с инакомыслящими. Если власть начинает сопротивляться, цветная революция переходит в фазу вооруженного мятежа. Иногда этот мятеж сопровождается вооруженной интервенцией со стороны западных стран, как это было в Ливии, и возможно будет в Сирии.

Цветные революции часто называют технологиями или инструментами «мягкой силы». Этот подход, основанный на принципе аналогии (внешне цветные революции - это несиловые технологии смены политических режимов), не совсем точен и часто вводит в заблуждение, заставляя считать цветные революции более мягкой и поэтому более прогрессивной и менее социально опасной формой воздействия на авторитарные режимы. Тем самым разворачивается кампания по пропаганде цветных революций в пику любым формам собственно вооруженных переворотов. На наш взгляд, трудно определить, что на самом деле является более опасным явлением для международной безопасности в целом: цветные революции или локальные вооруженные конфликты, и современный Ближний Восток, погруженный цветными революциями в «управляемый» хаос, является полным тому подтверждением. Все же, представляется довольно очевидным, что современные цветные революции по своей природе - это не форма проявления «мягкой силы». Цветные революции - это не что иное, как организационная форма осуществления государственного шантажа (то есть шантажа, объектом которого является независимое и суверенное государство), маскирующегося под легендой и лозунгами национальной революции.

Цветные революции - не мягкая сила; это инструменты взлома демократических режимов переходного типа, скопированных с англосаксонских образцов незападными странами, которые имеют признаки имитационности. Можно утверждать, что американцы не только создали модель демократического устройства государства, ориентированную «на экспорт», но и позаботились о создании специальных инструментов, предназначенных для ее слома и демонтажа, если в 
этом вдруг возникнет необходимость. В современном мире такими инструментами, играющими роль своеобразных отмычек для взлома политических режимов западного либерального типа, являются технологии цветных революций.

Очень важно понимать, что именно Россия сегодня ставит жирную точку в сценарии «Арабской весны», погрузившей мирный Ближний Восток и Северную Африку в кровавый хаос и стоивший странам, ставшим жертвами технологий цветных революций, сотен тысяч жизней их граждан, погибших в результате гражданских войн, под ударами авиации США и НАТО, уничтоженных исламистами, долгое время считавшихся Соединенными Штатами истинными «борцами за свободу и демократию». Россия, показавшая на деле, что с исламистами не только нужно, но и можно бороться, развеявшая миф о непобеди- мости ИГ, сегодня повсеместно на Арабском востоке воспринимается как сила, способная гарантировать послевоенный миропорядок, который установится после победы над ИГ и Аль-Кайдой. Именно поэтому к России тянутся за помощью и защитой, Россия стала центром притяжения для всего Арабского мира, единственной силой, способной защитить от ИГ, цветных революций и «управляемого хаоса». Если бы не Россия, режим Асада бы через некоторое (не очень большое) время неизбежно бы пал, тем самым позволив американцам довести «Сирийскую весну» до финала, предусмотренного сценарием цветной революции. То, что этого не произошло, свидетельствует о том, что в мире появилась новая сила, способная дать решительный отпор цветным революциям, в какой бы форме и под каким бы идеологическим прикрытием они не применялись.

\section{Библиография:}

1. Генштаб отчитался об итогах работы российских ВКС в Сирии за месяц. / Lenta.py. 2015, 30 окт. [Электронный документ] URL: http://lenta.ru/news/2015/10/30/targets/ (дата обращения 7.11.2015)

2. Гушер А.И. Геополитические и стратегические аспекты операции Воздушно-космических сил России в Сирии. // Конфликтология / nota bene. 2015. №4.

3. РИА Новости [Электронный документ] URL: http://ria.ru/radio_brief/20151007/1298159965.html\#ixzz 3o4rBw9Zf (Дата обращения 7.11.2015)

4. Spiegel: Россия положила конец мировому господству США. [] URL: https://russian.rt.com/inotv/2015-10-12/SpiegelRossiya-polozhila-konec-mirovomu (Дата обращения 7.11.2015)

5. Кара-Мурза С. Экспорт революции: Саакашвили, Ющенко... М. 2005.

6. Гушер А.И. Вызовы и угрозы безопасности России // Мировая политика. - 2014. - 1. - С. 64 - 75. DOI: 10.7256/24098671.2014.1.10748. URL: http://www.e-notabene.ru/wi/article 10748.html

7. Буневич Д.С. Крымский кризис 2014 года и создание новой архитектуры международных отношений // Конфликтология / nota bene. - 2015. - 2. - C. 133 - 139. DOI: 10.7256/2409-8965.2015.2.14333.

8. Бочарников И.В. Неядерное сдерживание как фактор обеспечения безопасности и суверенитета России в современных условиях // Тренды и управление. - 2015. - 2. - C. 120 - 128. DOI: 10.7256/2307-9118.2015.2.14226.

\section{References (transliterated):}

1. Gusher A.I. Geopoliticheskie i strategicheskie aspekty operatsii Vozdushno-kosmicheskikh sil Rossii v Sirii. // Konfliktologiya / nota bene. 2015. №4.

2. Kara-Murza S. Eksport revolyutsii: Saakashvili, Yushchenko... M. 2005.

3. Gusher A.I. Vyzovy i ugrozy bezopasnosti Rossii // Mirovaya politika. - 2014. - 1. - C. 64 - 75. DOI: 10.7256/24098671.2014.1.10748. URL: http://www.e-notabene.ru/wi/article_10748.html

4. Bunevich D.S. Krymskii krizis 2014 goda i sozdanie novoi arkhitektury mezhdunarodnykh otnoshenii // Konfliktologiya / nota bene. - 2015. - 2. - C. 133 - 139. DOI: 10.7256/2409-8965.2015.2.14333.

5. Bocharnikov I.V. Neyadernoe sderzhivanie kak faktor obespecheniya bezopasnosti i suvereniteta Rossii v sovremennykh usloviyakh // Trendy i upravlenie. - 2015. - 2. - C. 120 - 128. DOI: 10.7256/2307-9118.2015.2.14226. 